\title{
Performance of pit latrines in urban poor areas: A case of Kampala, Uganda
}

\section{Anne Nakagiri ${ }^{1 *}$, Robinah N. Kulabako ${ }^{1}$, Philip M. Nyenje ${ }^{1}$, John B. Tumuhairwe $^{2}$, Charles B. Niwagaba ${ }^{1}$, Frank Kansiime ${ }^{3}$}

${ }^{1}$ Department of Civil and Environmental Engineering, College of Engineering, Design, Art and Technology; Makerere University, P.O. Box 7062, Kampala Uganda.

${ }^{2}$ Department of Agricultural Production,

College of Agricultural and Environmental Sciences; Makerere University, P.O. Box 7062, Kampala Uganda.

${ }^{3}$ Department of Environmental Management,

College of Agricultural and Environmental Sciences; Makerere University, P.O. Box 7062, Kampala Uganda.

*Corresponding author address: Email address: anakagiri@gmail.com, Tel:

$$
+256-772-520394
$$




\begin{abstract}
In many urban poor areas of Sub-Saharan Africa (SSA), demand for human excreta disposal is met, predominantly by pit latrines. This study aimed at determining the status of pit latrines (design, construction, operation and maintenance) and its influence on latrine performance (filling, smell and insect nuisance). The study was conducted on 130 pit latrines in typical urban poor areas of Kampala, Uganda. Data on design, construction, usage, operation and performance of the pit latrines was collected by interviews, observations and measurements; and analysed by descriptive statistics, bi-variate analysis and logistic regression. Results showed that the level of pit content was predicted by rain or storm water entry, terrain, cleaning before or after use and number of households using the latrine. Smell was predicted by cleanliness, stance length, superstructure material and whether the latrine was private or public. The predictor of presence of flies was the superstructure material. To improve the performance of pit latrines in urban poor areas, researchers and practitioners should develop local latrine design standards (dimensions, construction materials and number of users) and cleaning guidelines for local policy makers to implement.
\end{abstract}

\title{
Keywords
}

Maintenance, operation, performance, pit latrines, smell, urban poor

\section{Introduction}

Access to improved sanitation in urban poor areas of developing countries is low. Urban poor areas, commonly referred to as slums, are heavily populated areas, characterized by substandard and unplanned infrastructure, poverty, and lack basic services like water and sanitation (Struyk \& Giddings, 2009; UN-HABITAT, 2009). Human excreta disposal in urban slums of Sub-Saharan Africa (SSA) is predominantly by use of pit latrines (Thye et al., 2011; Katukiza et al., 2012). Pit latrines have been adopted and are used because of their low cost, simplicity of construction and ease of operation and maintenance. However, their use in urban slums is characterised by several challenges. Jenkins et al. (2014) reported that some of the pit latrines in Tanzania did not meet the criteria of hygiene, safety and sustainability of sanitation systems because they were full or overflowing. Pit latrines in central Tanzania, were found to have high numbers of Culex quinquefasciatus mosquitoes, Chrysomya putoria and Psychodidae fly families (Irish et al., 2013). In Kenya, Caruso et al. (2014) found that the disgusting smell of latrines prevented their use by primary school pupils. Smell, flies and high filling rates are problems that have been associated with pit latrine use in Kigali, Rwanda (Tsinda et al., 2013). In slums of Kampala Uganda, Kwiringira et al. (2014a) reported high pit filling rates and smell as barriers for latrine 
usage and subsequently open defecation. Earlier, Tumwebaze et al. (2012), faulted smell as one of the reasons for user dissatisfaction with use of their pit latrines.

Understanding the design, construction, operation and maintenance of pit latrines within urban slum contexts could help come up with strategies to improve their performance in these settings. Research has shown that the presence of a door, superstructure quality (in terms of height and construction materials for walls) as well as the slab type, affect the cleanliness of a latrine (Sonego \& Mosler, 2014). Absence of a roof over the latrine and temporary superstructures as opposed to brick superstructures positively correlated with high numbers of flies (Irish et al., 2013). Relatedly, models on pit latrine filling have shown that adding non-degradable material into the pit and water inflows significantly influenced its filling (Brouckaert et al., 2013; Todman et al., 2014). Although not statistically related, smell has also for long been known as a proxy for dirty toilets.

The aim of this paper is therefore to determine the status of pit latrine structures, in terms of design, construction, operation and maintenance and the influence of these factors on their performance (filling, smell and insects nuisances) in a typical urban slum area.

\section{Materials and Methods}

\section{Study area}

This cross-sectional study was conducted in Kampala, the capital city of Uganda. Kampala has a population of 1.79 million people (UBOS, 2013), of which about 60\% resides in slums (Rugadya et al., 2008). This research is part of a study being undertaken to enhance the performance of pit latrines in slums of Kampala Uganda, focusing on Lufula Zone in Bwaise II Ward/parish, Kawempe Division. To get information more representative of Kampala, other zones within Bwaise II parish and slums spread across the five divisions of Kampala, which are known to house different ethnic groups were included in this research. The slums outside of Bwaise II were, Kasubi in Rubaga Division; Naguru-Godown and Kinawataka in Nakawa Division; Kifumbira in Kawempe Division; Kisenyi in Central Division and Namuwongo in Makindye Division (Figure 1). 


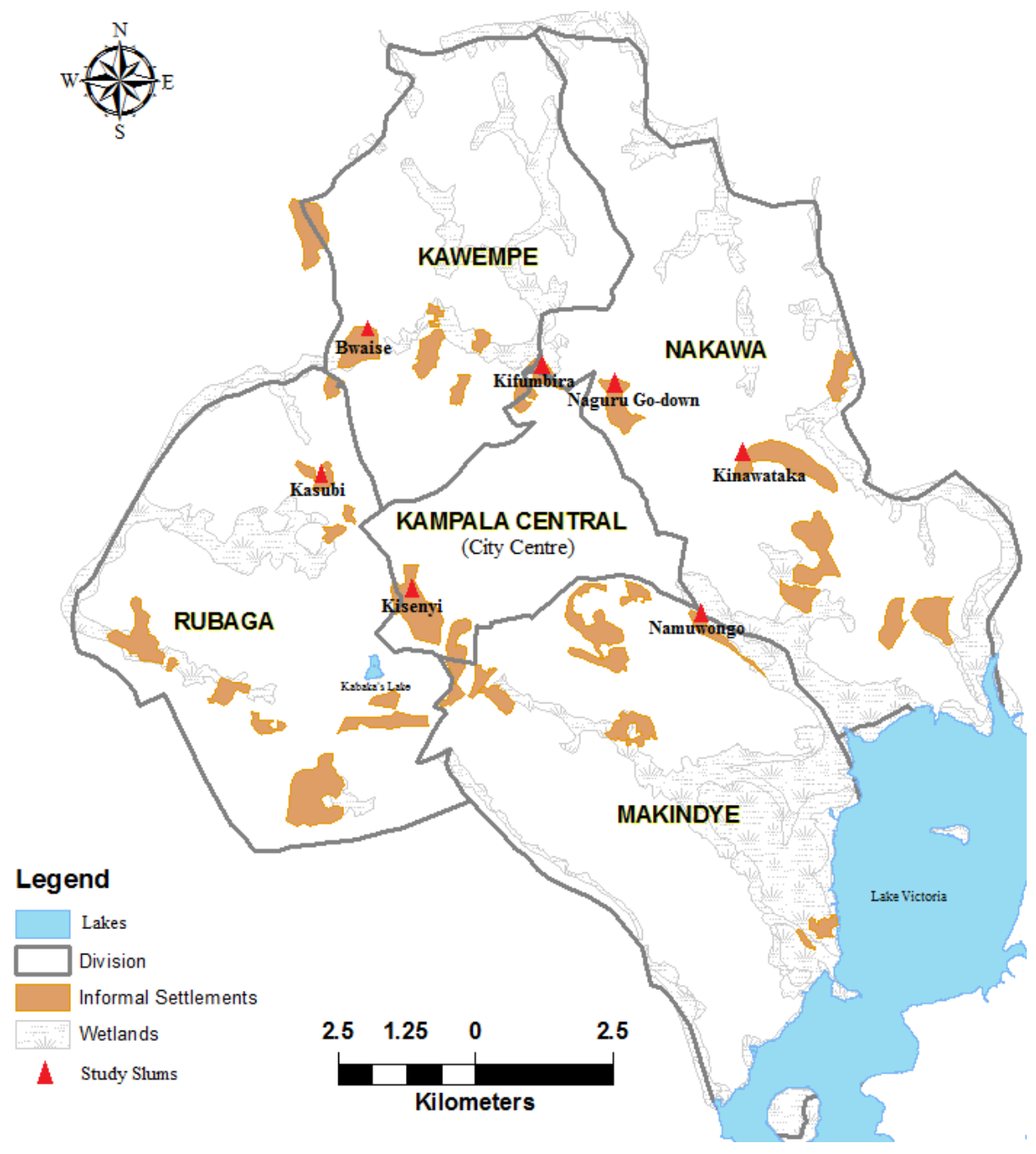

Figure 1: Map of Kampala Capital City showing the study slums

\section{Data collection}

Data was collected from traditional/simple and ventilated improved pit (VIP) latrines, which are used by $95 \%$ of the households in slums of Kampala (Tumwebaze et al., 2012). All (38) pit latrines, were assessed within Lufula zone, Bwaise II. In addition, 44 pit latrines were randomly selected and assessed in the other zones of Bwaise II and 48 from other slums of Kampala, outside of Bwaise II. In total, therefore, 130 pit latrines were studied.

Information in this study was obtained through field observations, measurements and user interviews. Data collected during observations and measurements of the pit latrines included facility design, stance size, materials used for construction, the structural condition of the latrine, presence of bad smell, and flies or other insects. Presence of bathroom, hand washing facilities and areas used for disposal of greywater were also noted. In addition, whether or not, the latrine had an access manhole for pit emptying was also noted. All information obtained was recorded in a pit latrine design assessment sheet. Questionnaires were used to record information obtained 
during the user interviews. The interview addressed the ways in which the pit latrines were operated, including public or private use, numbers and types of users, and the materials other than excreta, which were put in the pit. The details on latrine maintenance (cleaning and what is done when they are full) and user satisfaction were also noted.

\section{Data analysis}

The data were analysed using SPSS version 21. Descriptive statistics mainly percentages, means and standard deviations were used to describe the status of the pit latrines. Bivariate analysis (cross-tabulation and correlation) was used to establish variations within performance of pit latrines. The relationship between performance of pit latrines and their status was determined by binomial logistic regression, whereby a best fitting model was created, from which variables useful in predicting the performance factors were identified. The variables used in the regression analysis are listed in Table 1. All conditions for logistic regression including linearity and multicollinearity were satisfied. The difference in performance of the pit latrines between the flooded and non-flooded areas plus the different latrine design types was assessed using the ANOVA at a significance level of $95 \%$.

Table 1. Variables used in the logistic regression of pit latrine performance

\begin{tabular}{|c|c|c|c|c|c|c|}
\hline \multirow[t]{2}{*}{ Study aspect } & \multirow{2}{*}{$\begin{array}{l}\text { Variable name } \\
\text { (Factor) }\end{array}$} & \multirow{2}{*}{$\begin{array}{l}\text { Scale } \\
\text { (points) }\end{array}$} & \multirow[t]{2}{*}{ Description } & \multicolumn{2}{|c|}{ Parameter coding } & \multirow{2}{*}{$\begin{array}{l}\text { Assessment } \\
\text { used }\end{array}$} \\
\hline & & & & (1) & (2) & \\
\hline \multirow[t]{14}{*}{$\begin{array}{l}\text { Design and } \\
\text { construction }\end{array}$} & Type of pit latrine & 2 & $\begin{array}{l}\text { Simple or traditional - basic pit with a } \\
\text { slab and superstructure; } \\
\text { VIP - pit latrine with a vertical vent pipe }\end{array}$ & $\begin{array}{l}0=\text { Simple or } \\
\text { traditional } \\
1=\text { VIP }\end{array}$ & & Observation \\
\hline & Type of slab & 4 & Slab material & $\begin{array}{l}0=\operatorname{logs} \text { and mud; } \\
\text { timber }\end{array}$ & & \\
\hline & & & & $\begin{array}{l}1=\text { Smooth } ; \text { cracked } \\
\text { concrete slab }\end{array}$ & & Observation \\
\hline & Drop hole cover & 2 & Cover on hole in the slab & $0=$ no cover & & Observation \\
\hline & & & & $1=$ cover & & \\
\hline & Vent pipe & 2 & Vertical pipe from the pit & $0=$ no vent pipe & & \\
\hline & & & & $1=$ vent pipe & & Observation \\
\hline & $\begin{array}{l}\text { Superstructure } \\
\text { walls }\end{array}$ & 5 & & $\begin{array}{l}1=\text { mud and wattle, } \\
\text { polyethylene }\end{array}$ & $0=$ other & \\
\hline & & & & $0=$ others & $\begin{array}{l}1=\text { Timber, } \\
\text { roofing sheets }\end{array}$ & \\
\hline & Doors & 5 & Material used for construction & $\begin{array}{l}0=\text { Brick structures } \\
0=\text { Timber, metallic, } \\
\text { roofing sheets }\end{array}$ & $0=$ others & Observation \\
\hline & & & & $1=$ polyethylene, none & & \\
\hline & Roofing & 3 & & $0=$ roofing sheets & & \\
\hline & & & & $1=$ polyethylene, none & & \\
\hline & Pit type & 2 & $\begin{array}{l}\text { Ground level - Slab }<200 \mathrm{~mm} \text { above the } \\
\text { ground } \\
\text { Raised - Slab }>200 \mathrm{~mm} \text { above the ground }\end{array}$ & $\begin{array}{l}0=\text { Ground level } \\
1=\text { raised }\end{array}$ & & Measurement \\
\hline
\end{tabular}




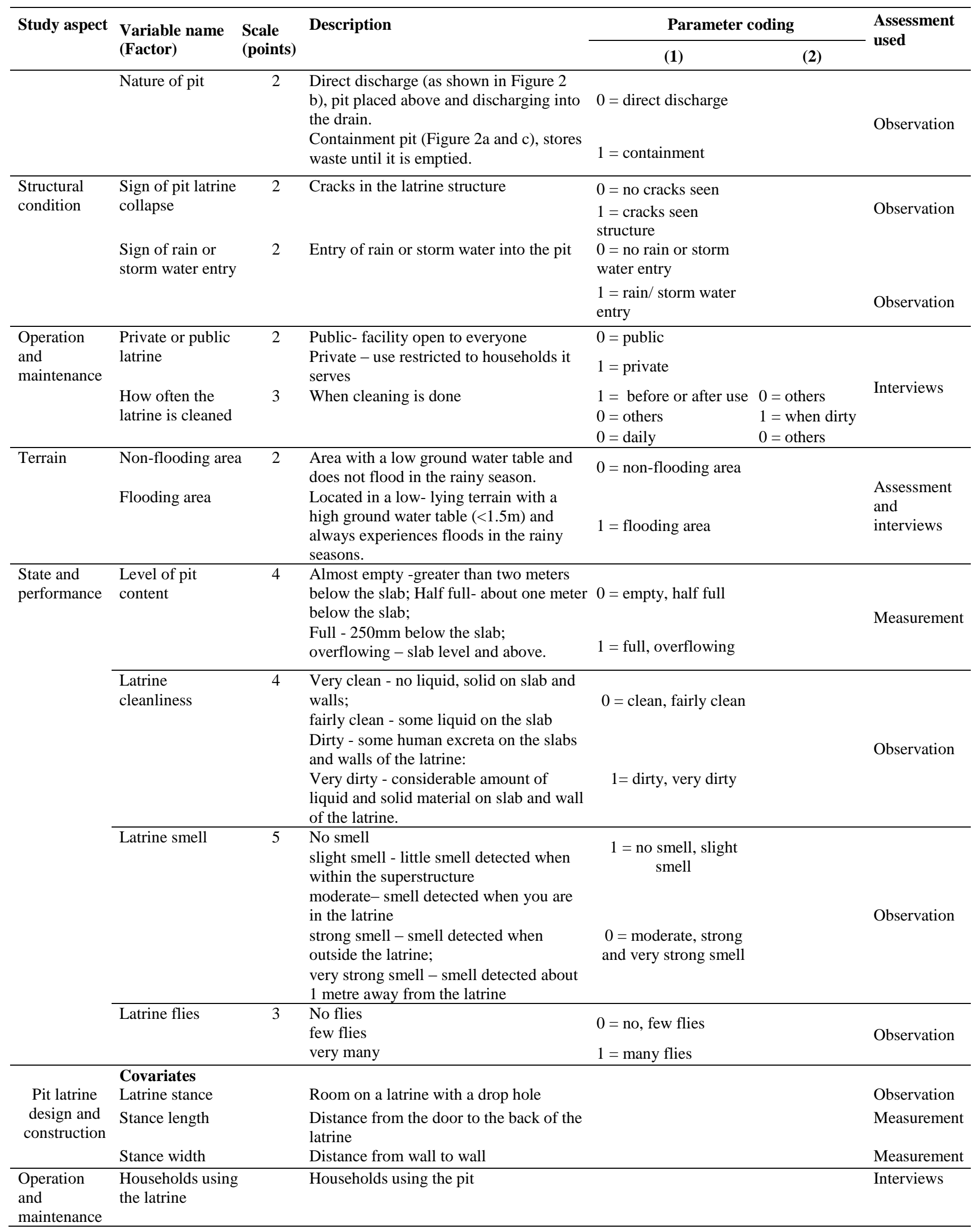




\section{Results}

\section{Design and construction of pit latrines}

The design, construction and structural condition of a pit latrine are important to ensure its proper functioning. The pit latrines in this study were all rectangular in shape, with VIPs and simple/ traditional types at about $23 \%$ and $77 \%$, respectively (Table 2). These were mainly built out of brick and plastered (77\%), with timber doors (89\%) and corrugated iron roofing sheets $(91 \%)$ although there existed facilities with either polyethylene or mud and wattle walls (Table 2). The vent pipes of the VIPs were all made out of uPVC, mainly grey in colour (87\%) and located within the superstructures (93\%). Additionally, all vent pipes lacked fly screens. Figure 2 shows existing pit latrine structures within the study area. Majority of latrines were constructed using strong and durable materials which met the recommended standards.

Table 2. Design and construction materials of pit latrine structures

\begin{tabular}{|c|c|c|c|c|}
\hline Variable $(n=130)$ & Category & Numb & entag & $\begin{array}{l}\text { Recommended standards } \\
\text { (Wagner \& Lanoix, 1958; Mara, } \\
\text { 1984; Franceys et al., 1992) }\end{array}$ \\
\hline \multirow[t]{2}{*}{ Pit latrine type } & VIP & 30 & 23 & \\
\hline & Simple/ traditional & 100 & 77 & \\
\hline Pit latrine shape & Rectangular & 130 & 100 & Rectangular, circular \\
\hline \multirow[t]{6}{*}{ Superstructure walls } & Plastered brickwork & 100 & 77 & \multirow{6}{*}{$\begin{array}{l}\text { Bricks/ blocks, stone, sawn } \\
\text { timber, bamboo, mud and wattle, } \\
\text { Ferro-cement, plasticized material } \\
\text { and galvanised/ aluminium sheets }\end{array}$} \\
\hline & Brickwork - not plastered & 16 & 12 & \\
\hline & Timber & 7 & 5 & \\
\hline & roofing sheets & 2 & 2 & \\
\hline & Polyethylene & 4 & 3 & \\
\hline & Mud and wattle & 1 & 1 & \\
\hline \multirow[t]{3}{*}{ Roofing } & Roofing sheets & 119 & 91 & \multirow{3}{*}{$\begin{array}{l}\text { Thatch, palm leaves, clay tiles, } \\
\text { fibre cement, wood shingles and } \\
\text { corrugated iron/ aluminium }\end{array}$} \\
\hline & Polyethylene & 6 & 5 & \\
\hline & None & 5 & 4 & \\
\hline \multirow[t]{5}{*}{ Doors } & Timber & 116 & 89 & \multirow{5}{*}{$\begin{array}{l}\text { Sawn timber, metal and no door in } \\
\text { case of spiral structures }\end{array}$} \\
\hline & Metallic & 1 & 1 & \\
\hline & Roofing sheets & 2 & 2 & \\
\hline & Polyethylene & 4 & 3 & \\
\hline & None & 7 & 5 & \\
\hline \multirow[t]{4}{*}{ Slab type } & Concrete smooth finish & 13 & 10 & \multirow{4}{*}{$\begin{array}{l}\text { Reinforced concrete /brick- } \\
\text { mortar, wood, timber and earth, } \\
\text { fabricated slabs and plain concert } \\
\text { slabs - for only simple pit latrines }\end{array}$} \\
\hline & Concrete cracked & 111 & 85 & \\
\hline & Logs and mud & 5 & 4 & \\
\hline & Timber & 1 & 1 & \\
\hline \multirow[t]{2}{*}{ Pit type } & Raised pit & 83 & 64 & \multirow{2}{*}{$\begin{array}{l}\text { Raised pit (high water table, un } \\
\text { even ground), else ground level }\end{array}$} \\
\hline & Ground pit & 47 & 36 & \\
\hline \multirow[t]{2}{*}{ Nature of pit } & Containment & 126 & 97 & \multirow[t]{2}{*}{ Containment pit } \\
\hline & direct discharge into drains & 4 & 3 & \\
\hline \multirow[t]{3}{*}{ Vent pipe* } & Vent has a fly screen & 0 & 0 & \multirow{3}{*}{$\begin{array}{l}\text { Fly screen on vent pipe } \\
\text { Black colour, uPVC, brick/block } \\
\text { and hollowed out bamboo }\end{array}$} \\
\hline & Grey uPVC & 26 & 87 & \\
\hline & Orange uPVC & 4 & 13 & \\
\hline
\end{tabular}

Note $* \mathrm{n}$ value for vent pipe $=30$ 
(c)
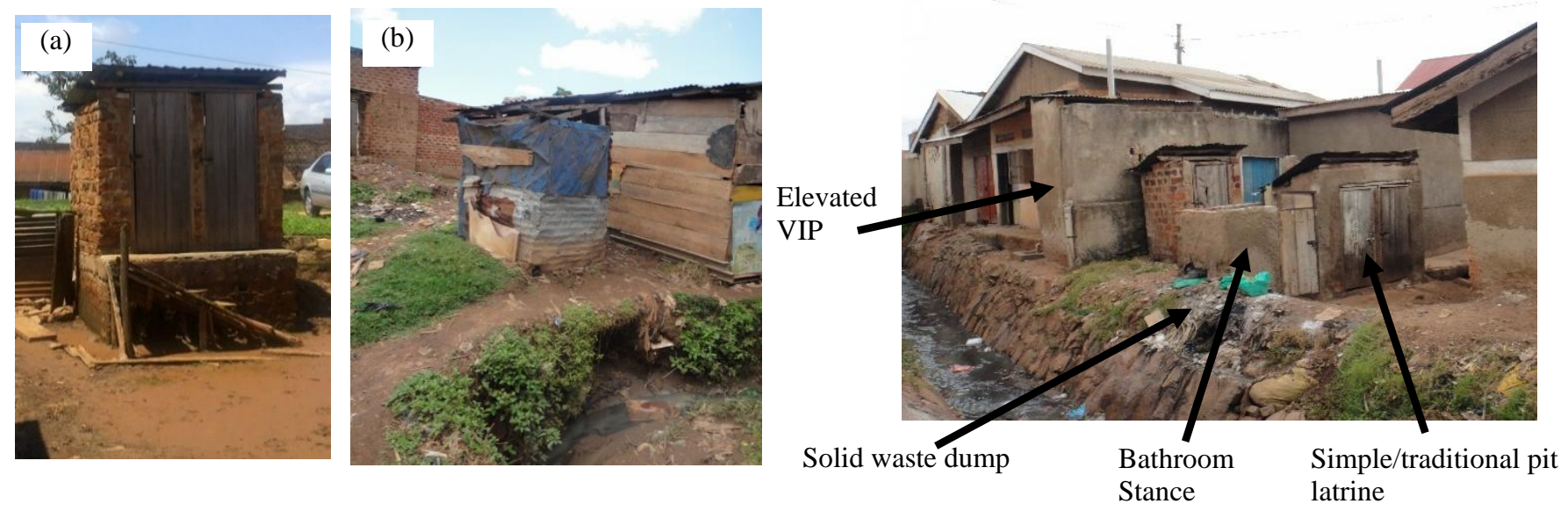

Figure 2: Pit latrine structures in Kampala urban slums (a) Elevated pit latrine in a flood prone area in Bwaise II Parish (b) Pit latrine constructed over and discharging directly into an open drain in Namuwongo (c) Elevated ventilated pit latrine and a simple pit latrine with an attached bathroom located in a non-flooding area

The number of stances per pit latrine ranged from 1 to 10 , with a mean value of 2 (Table 3 ). The brick built structures had up to 10 stances, while timber, polyethylene, mud and wattle and roofing structures were limited to 2 stances. All pit latrine superstructures were placed directly above the slab. The slabs were all squat type, majority made of concrete (95\%) of which only $10 \%$ were found to be smooth (Table 2). The minimum drop-hole length was $180 \mathrm{~mm}$ and the maximum width was $150 \mathrm{~mm}$ (Table 3 ).

Table 3. Pit latrine measurements

\begin{tabular}{|c|c|c|c|c|c|c|}
\hline Variable & $N$ & Min. & Max. & Mean & SD & $\begin{array}{l}\text { Recommended standard } \\
\text { (Wagner \& Lanoix, 1958; } \\
\text { Mara, 1984; Franceys et al., } \\
\text { 1992) }\end{array}$ \\
\hline Stances number & 130 & 1 & 10 & 2.4 & 1.5 & \\
\hline \multicolumn{7}{|l|}{ Stance dimensions } \\
\hline Length (mm) & 130 & 700 & 2060 & 1186 & 254 & \\
\hline Width (mm) & 130 & 500 & 1800 & 918 & 206 & \\
\hline Height (mm) & 130 & 1670 & 2200 & 1990 & 282 & $\geq 2000$ \\
\hline \multicolumn{7}{|l|}{ Drop hole dimensions } \\
\hline Length (mm) & 130 & 180 & 250 & 226 & 25 & $\begin{array}{l}\geq 350 \text { (to prevent soiling the } \\
\text { drop hole) }\end{array}$ \\
\hline Width (mm) & 130 & 100 & 150 & 114 & 22 & $\begin{array}{l}\leq 200 \text { (to prevent children from } \\
\text { falling in) }\end{array}$ \\
\hline Vent pipe dimensions (mm) & 30 & 100 & 150 & 107 & 17 & $\geq 150($ for $u P V C)$ \\
\hline $\begin{array}{l}\text { Height of stance above the } \\
\text { ground }(\mathrm{mm})\end{array}$ & 81 & 400 & 2000 & 935 & 412 & \\
\hline
\end{tabular}

The latrine slabs were placed directly over a single pit that was either sunk in the ground $(36 \%)$ or elevated above the ground to a mean height of $935 \mathrm{~mm}$ (Table 3). Raised pit latrines were found in both terrains (Table 4), although the number and height of pit were significantly higher $(p \leq 0.001)$ in the flooding areas. Elevated pits were all constructed using plastered brick work. 
Access to the elevated pit latrines was by concrete steps (61\%), ramp (10\%) or ladders $(25 \%)$ and in some cases none (4\%). Some pit latrines (47\%) were constructed with an attached bathroom stance (Figure 2), majority of which $(82 \%)$ were discharging their grey water into open drains. Almost all pit latrines (98\%) lacked hand washing facilities.

Table 4. Pit type and condition of pit latrines $(n=130)$

\begin{tabular}{|c|c|c|c|c|}
\hline Variable & Category & $\begin{array}{l}\text { Flooding } \\
\text { area }(\%)\end{array}$ & $\begin{array}{l}\text { Non-flooding } \\
\text { area }(\%)\end{array}$ & $\begin{array}{l}\text { Total } \\
(\%)\end{array}$ \\
\hline \multirow[t]{2}{*}{ Pit type } & Raised pit & 49 & 15 & 64 \\
\hline & Ground level pit & 4 & 32 & 36 \\
\hline \multirow{2}{*}{$\begin{array}{l}\text { Structural condition of the } \\
\text { pit latrine }\end{array}$} & Signs of collapse & 28 & 11 & 39 \\
\hline & no signs of collapse & 25 & 36 & 61 \\
\hline \multirow[t]{2}{*}{ Storm water entry } & $\begin{array}{l}\text { Signs of rain/ storm water } \\
\text { entry }\end{array}$ & 30 & 10 & 40 \\
\hline & $\begin{array}{l}\text { no signs of rain/ storm water } \\
\text { entry }\end{array}$ & 23 & 37 & 60 \\
\hline Total Pit latrines & & 53 & 47 & 100 \\
\hline
\end{tabular}

Thirty nine percent of the pit latrines had cracks while $40 \%$ showed signs of rain or storm water entry (Figure 3). This indicates that some of the latrines were not structurally sound. Significant differences were noted between the structural condition of pit latrines in both terrains $(p \leq 0.001)$ with more latrines having cracks and showing signs of rain or storm water entry in flooding areas. With regard to the construction materials, most of the plastered brick structures were structurally sound while more of the non-plastered ones showed signs of collapse and rain or storm water entry. All polyethylene and mud/wattle structures showed signs of collapse and rain or storm water entry (Figure 3).

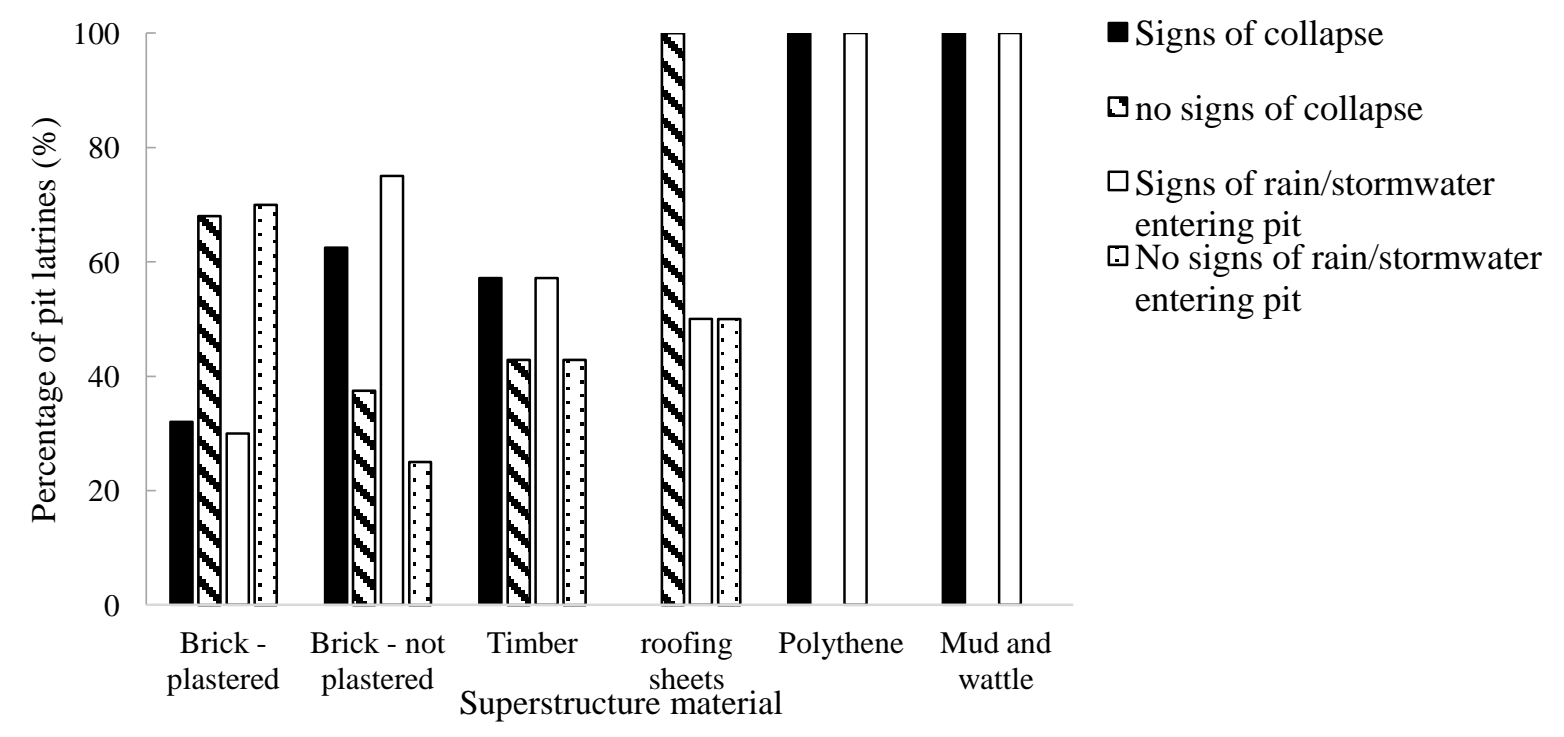

Figure 3: Structural condition of different pit latrine superstructures 


\section{Operation and maintenance of latrines}

Operation and maintenance of a pit latrine is crucial for its performance. Majority of the pit latrines $(85 \%)$ were operated as private to households, shared by mostly $5-8$ households, although up to 20 households were found using a single latrine stance. The use of pit latrines as public facilities was at only $15 \%$. The mean number of people per household was 4.5 . Children were present in majority of the households while only $8 \%$ of the respondents stated having elderly in their homes and 4\% lived with people with disabilities (PWD). The use of pit latrines by children, elderly and PWD in this study was reported by $12 \%$ of the respondents.

Human excreta, sanitary products (baby diapers and menstrual pads), and anal cleansing material ( $85 \%$ of which were newspapers) were deposited in the pits. Very few respondents (4\%) reportedly disposed solid waste/ rubbish in the pit latrines. The solid waste was dumped besides pit latrines as shown in Figure 2. Pit latrine cleaning was by use of water and detergents that ended up in the pit. Cleaning was mainly done (66\%) before or after each use of the latrine and by every user $(75 \%)$. Almost all the pit latrines (95\%) contained their excreta until they were emptied. The rest discharged directly into open drains and these were all found in flooding areas. Additionally, pits in non-flooding areas were constructed as leach pits while those in flooding areas were said to be fully lined. Majority of the pit latrines had a filling time of 1 to 3 months, with longer filling time experienced in latrines located in non-flooding areas (Figure 4 a). Upon filling, $59 \%$ of the pit latrines were reportedly emptied, while $11 \%$ of the users supposedly dug new pits (Figure 4 b). Only $5 \%$ of the latrines were constructed with access manholes for emptying.
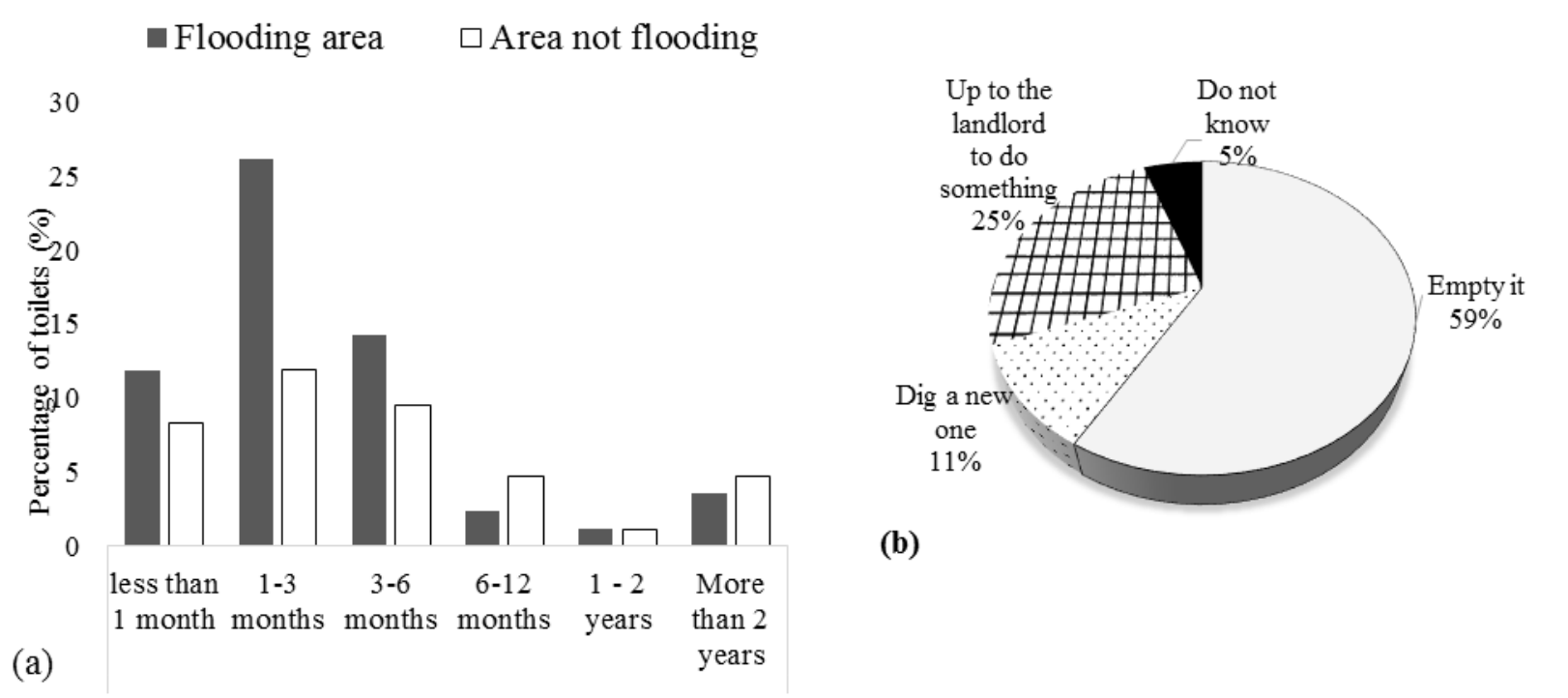

(b)

Figure 4 (a) Pit latrine filling time; and (b) frequencies of action taken when the pit latrine is full 


\section{Performance of pit latrines}

Majority of the latrines were full (51\%) or over flowing (15\%) (Table 5). A strong malodorous smell was noted in $39 \%$ of the latrines while few flies were found in majority (80\%) of the latrines. Most of the latrines (43\%) were dirty. Although respondents' satisfaction with the use of their facilities was high (52\%), majority of them (89\%) expressed the need to improve the state and performance of the pit latrines.

Table 5. Performance of pit latrines

Performance variables

Pit latrines $(\%)$

\section{Level of pit content}

Almost Empty

Half full 27

Full 51

Overflowing

\section{Smell of Latrine}

No smell

Slight smell 35

Moderate smell

Strong smell

Very strong smell

Fly presence

No

Few

Many

Cleanliness

Clean

Fairly Clean

Dirty

Very Dirty

User Satisfaction

Yes 
Comparison of means between pit latrines in different terrains (flooding to non-flooding) showed a significantly higher level of pit content $(p=0.036)$ and smell of pit latrines $(p=0.031)$. Further, analysis was undertaken to assess the performance (smell and flies) of the different pit latrine designs. A comparison of performance variable means of the different pit latrine designs was only significant for smell. Significantly higher smell levels were noted in traditional compared to the VIP and simple pit latrines.

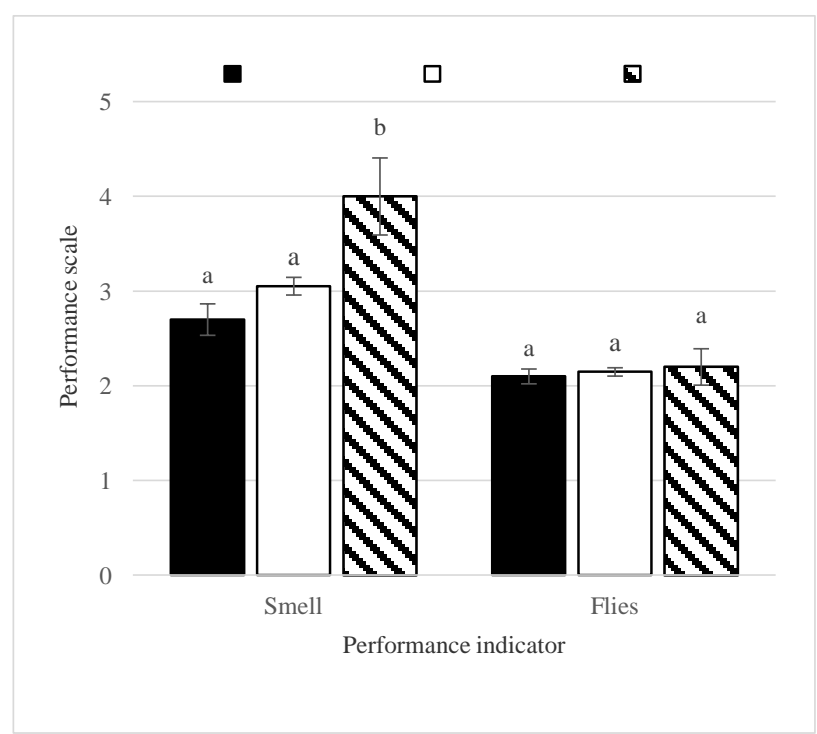

Figure 5 Smell and fly levels (Mean \pm Standard error) in the different pit latrine designs within the slums. Means with different letters for perceived levels are significantly different $(p<0.05)$.

\section{Relating status of the pit latrines to their performance}

A logistic regression was performed to ascertain the effects of different design, construction operation and maintenance variables on the likelihood that pit latrines were full, smelling or had flies. The results of the values of the chi-square distribution for the 3 models (level of pit content, smell and fly nuisance) were all significant at 5\% level (Table 6). The models explained 59\%, $75 \%$ and $51 \%$ (Nagelkerke $R^{2}$ ) of the variance in the pit content level, smell and flies in the latrines respectively, indicating a moderately strong relationship between the predictors and performance variables. 


\begin{tabular}{|c|c|c|c|c|c|c|c|}
\hline \multirow{3}{*}{ Predictor Variables } & & \multicolumn{6}{|c|}{ Performance variables } \\
\hline & & \multicolumn{2}{|c|}{ Level of pit content } & \multicolumn{2}{|c|}{ Smell of pit latrine } & \multicolumn{2}{|c|}{ Fly presence } \\
\hline & & $B(S E)$ & Odds Ratio & $B(S E)$ & Odds Ratio & $B(S E)$ & Odds Ratio \\
\hline \multirow{4}{*}{$\begin{array}{l}\text { Design and } \\
\text { construction }\end{array}$} & (Constant) & -43.9 & & 12.4 & & -40.9 & \\
\hline & Stance length & $0.0(0.0)$ & 1.0 & $0.0^{\mathbf{b}}(0.0)$ & 1.0 & $0.0(0.0)$ & 1.0 \\
\hline & Superstructure (timber, roofing) & $-2.0(1.8)$ & 0.1 & $-5.0^{\mathrm{c}}(2.0)$ & 0.01 & $4.3^{c}(2.1)$ & 70.6 \\
\hline & Raised pit & $-1.5(1.2)$ & 0.2 & $2.1^{\mathrm{d}}(1.1)$ & 7.9 & $1.7(1.4)$ & 5.8 \\
\hline \multirow{2}{*}{$\begin{array}{l}\text { Structural condition } \\
\text { of Pit latrine }\end{array}$} & Sign of pit latrine collapse & $0.4(0.9)$ & 1.5 & $0.0(1.1)$ & 1.0 & $1.9^{d}(1.1)$ & 6.4 \\
\hline & Sign of rainstorm water entry & $3.5^{\mathrm{a}}(1.2)$ & 34.6 & $-0.7(1.1)$ & 0.5 & $-0.2(1.1)$ & 0.9 \\
\hline \multirow{3}{*}{$\begin{array}{l}\text { Operation and } \\
\text { maintenance }\end{array}$} & Flooding area & $1.7^{d}(0.9)$ & 5.3 & $1.2(1.1)$ & 3.3 & $-2.3^{\mathrm{d}}(1.2)$ & 0.1 \\
\hline & Private to households only & $-0.9(1.7)$ & 0.4 & $-4.5^{\mathrm{c}}(2.2)$ & 0.01 & $20.9(3 \mathrm{E}+04)$ & $1 \mathrm{E}+09$ \\
\hline & Cleaning - every after / before use & $1.6^{\mathbf{c}}(0.7)$ & 5.0 & $-3.7^{\mathbf{b}}(1.3)$ & 0.02 & $1.3(1.0)$ & 3.6 \\
\hline $\begin{array}{l}\text { State and } \\
\text { performance of the } \\
\text { latrine }\end{array}$ & latrine cleanliness & $N A$ & & $4.6^{\mathrm{a}}(1.1)$ & 97.6 & $1.3(1.3)$ & 3.8 \\
\hline \multirow{2}{*}{\multicolumn{2}{|c|}{$\begin{array}{l}\text { Notes: } \mathrm{B}=\text { regression coefficient } \\
\mathrm{SE}=\text { standard error } \\
\mathrm{R}^{2}=\text { measure of goodness of model fit } \\
\text { determined using the Cox \& Snell and } \\
\text { Nagelkerke approaches } \\
\text { Method = the entry method }\end{array}$}} & \multicolumn{2}{|c|}{$\begin{array}{l}\text { Model } X^{2}(15, \mathrm{~N}=108)=61.4 \\
p<0.001,81.5 \text { (\%predicted) } \\
\mathrm{R}^{2}=0.43 \text { (Cox \& Snell), } 0.59 \\
\text { (Nagelkerke) }\end{array}$} & \multicolumn{2}{|c|}{$\begin{array}{l}\text { Model } X^{2}(22, \mathrm{~N}=107)=86.8 \\
p<0.001,86(\% \text { predicted }) \\
\mathrm{R}^{2}=0.56(\text { Cox \& Snell }), 0.75 \\
(\text { Nagelkerke })\end{array}$} & \multicolumn{2}{|c|}{$\begin{array}{l}\text { Model } X^{2}(22, \mathrm{~N}=107)=37.6 \\
p=0.02,90.7(\% \text { predicted }) \\
\mathrm{R}^{2}=0.30(\text { Cox \& Snell }), 0.51 \\
\text { (Nagelkerke) }\end{array}$} \\
\hline & & \multicolumn{4}{|c|}{$\mathbf{a}_{p<0.001,}{ }_{p<0.01,}^{\mathbf{b}_{p}}{ }_{p<0.05,}^{\mathbf{d}_{p<0}}$} & & \\
\hline
\end{tabular}

The Wald statistics demonstrated that signs of rain/ storm-water entry $(\beta=34.6)$, flooding area $(\beta=5.3)$, and cleaning before or after use $(\beta=5.0)$ had a statistically significant relationship with the level of pit content. The odds that a pit latrine with signs of storm water entry being full are higher than those without signs. Pit latrines located in flooding areas were also more likely to be full than those in non-flooding areas, while frequently cleaned latrines (every before/after use) had a higher level of pit content.

Cleanliness was the strongest predictor $(\beta=97.6)$ of smell, implying that a dirty pit latrine was 97.6 times more likely to smell badly than a clean one. Other predictors with a notable small influence on smell were the stance length $(\beta=1.0)$, superstructure material (timber or roofing sheets, $\beta=0.01$ ), latrine use by households only $(\beta=0.01)$ and cleaning before/after use $(\beta=0.02)$. 
The predictor of fly presence was superstructure material $(\beta=70.6)$. Timber /roofing sheet superstructures were more likely to have flies than those made of brick. Other variables that could influence the fly presence at a low significant level $(\mathrm{p}<0.1)$ were flooding areas and signs of collapse (Table 6).

The type of the pit latrine; its slab; presence of a drop hole cover; having a vent pipe; door and roofing material; nature of the pit; number of stances; stance width and number of households using the latrine were not significant predictors of the performance of the pit latrines. Although some of the variables were non-significant predicators, they significantly correlated with the performance of the pit latrines and can thus influence it. For instance, significant Pearson correlations were noted for containment pit $(r=-0.249, p<0.001)$ and pit elevation $(r=-0.240, p<0.001)$ with the level of pit content.

Binomial logistic regression analysis was carried out to predict the influence of the status of pit latrine structures on their performance in Lufula Zone in Bwaise II Ward/parish, Kawempe Division (Table 7). The results of the values of the chi-square distribution were significant for only the level of pit content and smell of the latrines. This indicates that the models including the predictors, significantly predict only the level of pit content and smell of the pit latrines.

Table 7. Logistic regression predictors of level of pit content

\begin{tabular}{|c|c|c|c|}
\hline & \multicolumn{3}{|c|}{ Performance indicators } \\
\hline & Level of pit content & Smell & Fly presence \\
\hline Model Chi-square & $\begin{array}{l}X^{2}(1, \mathrm{~N}=38)=12.14, \\
p<0.001\end{array}$ & $\begin{array}{l}X^{2}(2, \mathrm{~N}=38)=24.803 p< \\
0.001\end{array}$ & $\begin{array}{l}\text { Initial }-2 \log \\
\text { likelihood = } 15.67\end{array}$ \\
\hline \multirow{2}{*}{$\begin{array}{l}\mathrm{R}^{2} \text { (Nagelkerke), } \\
\% \text { predicted }\end{array}$} & 0.37 & 0.65 & - \\
\hline & 73.7 & 84.2 & 94.7 \\
\hline \multirow[t]{10}{*}{ Significant predictors } & \multicolumn{3}{|l|}{ Variables in equation } \\
\hline & \multirow{4}{*}{$\begin{array}{l}\text { Households using the pit } \\
\text { latrine } \\
B(S E)=0.435(0.16)^{\mathrm{b}} \\
\text { Odds Ratio }=1.55\end{array}$} & Raised pit & Constant only \\
\hline & & $B(S E)=3.311(1.16)^{\mathrm{b}}$ & \\
\hline & & Odds Ratio $=27.4$ & \\
\hline & & Latrine cleanliness & \\
\hline & & $B(S E)=2.97(1.17)^{\mathrm{c}}$ & \\
\hline & & Odds Ratio $=19.46$ & \\
\hline & \multicolumn{2}{|c|}{ Variables not in equation (all significant at $p=0.1$ ) } & \\
\hline & Flooding area & \multirow[t]{2}{*}{ Flooding area } & Raised pit \\
\hline & Rain or storm water entry & & $\begin{array}{l}\text { Superstructure } \\
\text { material } \\
\text { Cleanliness }\end{array}$ \\
\hline
\end{tabular}

Notes: ${ }^{\mathbf{a}} p<0.001,{ }_{p}^{\mathbf{b}}<0.01,{ }_{p<0.05,}^{\mathbf{d}} p<0.1 ; \mathrm{B}=$ regression coefficient; SE = standard error method - Forward Stepwise (Likelihood Ratio) method 
Nagelkerkes $\mathrm{R}^{2}$ indicated a moderately strong relationship between the predictors and smell (65\%) and a weak relationship for level of pit content (37\%). The main predictor of level of pit content was the number of households using the latrine. Other significant variables that did not contribute to the models ability to predict the level of pit content were flooding area and signs of rain or storm water entry. Smell was predicted, first by whether the pit was above the ground, followed by latrine cleanliness while fly presence had no significant predictors. Comparison of the results of slums in this study as a whole to those of Lufula zone (Table 6 and 7) indicates possibility of having different predictors of pit latrine performance between slums.

\section{Discussion}

\section{Status of pit latrine structures}

Majority of the pit latrines were simple or traditional, with only three VIPs in every 10 latrines. The design adapted consisted of a rectangular brick superstructure, with timber doors and roofing sheets, having single or multiple stances over a squat type slab placed directly above a single pit (Figure 1). From the technical perspective (Cotton et al., 1995) and the JMP classification of sanitation facilities (UNICEF \& WHO, 2008), majority of the facilities in this study could be considered as improved pit latrines. However, there were differences and shortfalls in their construction, usage and performance.

In this study, raised pit latrines were also found in non-flooding area, perhaps due to the need for increasing the pit volume as siting new pits in slums is a challenge. The VIP latrines in this study did not meet the recommended design standards. Further, findings show that the use of polyethylene and mud/wattle structures may not be appropriate for urban slums. Majority of the pit latrines in this study were satisfactory for use by children as they had solid concrete slabs and a drop hole width less than 200mm (Mara, 1984; Franceys et al., 1992). However, access to pit latrines by PWD and the elderly was least considered in the design. Ramps were limited to only $10 \%$ of the pit latrines. This could be due to the low occupancy of PWD and the elderly within the households. Factors that could also have hindered proper construction of pit latrine structures are limited funds, lack of design knowledge and no enforcement to ensure good facilities (Medland et al., 2015).

The performance of pit latrines in this study was found to be inadequate. Seven in every ten pit latrines were either full or overflowing and majority of them filled in three months or less. The smelling nature of pit latrines and the presence of flies, which this study found, are consistent with findings from other studies conducted in urban slum settings (Kulabako et al., 2010; Irish et al., 
2013; Jenkins et al., 2014). The use of full, smelly pit latrines that also have flies, is not only difficult but also risky to the health of the users as excreta is not properly isolated.

The use of private pit latrines shared by a number of households noted in this study is typical in slums of Kampala (Kulabako et al., 2010; Tumwebaze et al., 2012). Only about three in every ten latrines were used by the recommended four households according to the Uganda's national sanitation guidelines (MOH-Uganda, 2000), and less by two household threshold recommended by UN Habitat (UN-HABITAT, 2006). This signifies that pit latrines in urban slums of Kampala are over loaded.

Addition of waste streams other than human excreta in pit latrines was minimal in this study. Studies have reported presence of household rubbish/ garbage in pit latrine content (Buckley et al., 2008; Banks, 2014). The minimal disposal of other wastes in pit latrines could be due to the users being conscious of high filling rates of their latrines. Further, while disposal of sanitary wastes like baby diapers and menstrual pads in pit latrines was mentioned, earlier studies have shown that menstrual hygiene in slum is mainly by re-usable material owing to the expenses involved in buying pads (Kwiringira et al., 2014b). Therefore, other factors rather than external waste streams account for the poor performance of pit latrines in the studied slums.

\section{Relating status of pit latrines to their performance}

Logistic regression indicated a relationship between the status and performance variables of pit latrines in this study. Signs of rain or storm water entry, flooding and cleaning time were significant predictors of pit latrine filling. This is consistent with the findings in modelling pit filling by Todman et al. (2014) where it was noted that the flow and accumulation of water in the latrine has an important effect on the filling rate. Prevention of rain and storm water entry can be addressed in pit latrine construction through raising the slab to at least $150 \mathrm{~mm}$ above the ground and providing a roof on the latrine (Wagner \& Lanoix, 1958; Franceys et al., 1992). However, in flooding areas, it will be necessary to raise the slab to a level above the highest flood level. The high level of pit content in flooding areas was probably because the pits were small and shallow. In high water table areas, lining of large volume pits is expensive while digging deep pits is hindered by the ground water table. Further, entry of groundwater into the pits cannot be ruled out. While raised pit latrines were reportedly fully lined, research has shown that the contamination of shallow aquifers in slum areas of Kampala is attributed to wastewater infiltration from pit latrines (Nyenje et al., 2013; Nyenje et al., 
2014). Therefore, pit latrines are either not fully lined or they leak. Additionally the cleaning before/after use by a high user number implies an increase of water input into the pit.

The predictors of smell found in this study were cleanliness, stance length, superstructure material, use by households only and cleaning after/ before use of the latrine. Studies directly relating smell to cleanliness are limited. However, smell has always been proxy for dirty toilets. Household use of latrines and cleaning before or after use could result in cleaner latrines that smell less. Sonego and Mosler (2014) found habitual cleaning behaviour to be the strongest predictor of latrine cleanliness.

The length of the latrine stance as a predictor of smell could be linked to an increase in volume/ size of the pit latrine structure, which decreases the air exchange rate. Superstructures made out of timber/ roofing sheets on the other hand, have a higher airflow rates. According to Mara (1984), at high air exchange rates, odours are less likely to accumulate within the superstructure. Additionally the air exchange rate increases directly with ventilation rates, but decreases inversely with superstructure size.

Flies presence was related to superstructure material. Superstructures made out of timber/roofing sheets have more light within the superstructure unlike brick structures. As flies are phototropic (Wagner \& Lanoix, 1958; Irish et al., 2013) they will go into the timber/ roofing sheet structures.

Interestingly, while the improved designs performed better than the traditional pit latrine, the VIP did not provide superior performance (smell, flies) to the simple pit latrine. Additionally, VIPs were not likely to smell less and have fewer flies than simple pit latrines because they were not meeting the minimum design standards (Tables 2 and 3). This finding is similar to the findings by Dumpert (2008) who noted inadequate VIP design as a hindrance to their proper functioning. The shortfalls in the VIP design could be attributed to limited knowledge of the users about pit latrine designs. Secondly, overcrowding in the slums could impede ventilation within the VIPs to achieve odourless conditions. Variations in predictors of performance were observed at individual slum level. This could be due to variations in characteristics between slums.

\section{Conclusions}

The design of pit latrines in Kampala's slums was characteristically similar, but there were variations in the construction and operation/ usage and maintenance of the latrines. Further, the performance (filling, smell and insects' nuisance) of pit latrines was inadequate. Interventions to improve the 
performance of pit latrines should tackle their design and operation. Specific considerations should focus on minimising water inflows into the pit, increasing the air flow rate, minimising light in the superstructures and ensuring cleanliness of the latrines. Additionally, determining and ensuring adaptation of appropriate pit latrine standards is important. The findings from this research provide important information for slum settlements, which are known to have varying characteristics and is very informative for local policy makers, practitioners, researchers and donor agencies. It provides a basis for design modifications and recommendations for pit latrine use in slums.

\section{Acknowledgements}

This study was carried out as part of the research project "Stimulating Local Innovation on Sanitation for the Urban Poor in Sub-Saharan Africa and South-East Asia", which is funded by the Bill and Melinda Gates foundation through UNESCO-IHE partnership with Makerere University.

\section{References}

Banks, I. (2014). To assess the impact of black soldier fly (Hermetia illucens) larvae on faecal reduction in pit latrines. PhD Thesis, London School of Hygiene \& Tropical Medicine Available at: http://researchonline.Ishtm.ac.uk/1917781/ accessed on 20/11/2014.

Brouckaert, C., Foxon, K., \& Wood, K. (2013). Modelling the filling rate of pit latrines. Water SA, 39(4), 555-562.

Buckley, C. A., Foxon, K. M., Brouckaert, C. J., Rodda, N., Nwaneri, C. F., Balboni, E., Couderc, A., \& Magagna, D. (2008). Scientific support for the design and operation of ventilated improved pit latrines (VIPS) and the efficacy of pit latrine addtives. South Africa: Water Research Commission.

Caruso, B. A., Dreibelbis, R., Ogutu, E. A., \& Rheingans, R. (2014). If you build it will they come? Factors influencing rural primary pupils' urination and defecation practices at school in western Kenya. Journal of Water, Sanitation and Hygiene for Development, 4(4), 642-653.

Cotton, A., Franceys, R., Pickford, J., \& Saywell, D. (1995). On-Plot Sanitation in low-income urban communities. A review of literature. Loughborough, UK: WEDC Loughborough Univ. of Technology.

Dumpert, J. W. (2008). Performance Evaluation of VIP Latrines in the Upper West Region of Ghana. MSc Thesis, Michigan Technological University.

Franceys, R., Pickford, J., \& Reed, R. (1992). A guide to the development of on-site sanitation. London, England: World Health Organisation.

Irish, S., Aiemjoy, K., Torondel, B., Abdelahi, F., \& Ensink, J. H. J. (2013). Characteristics of Latrines in Central Tanzania and Their Relation to Fly Catches. PLoS ONE 8(7), e67951. doi:67910.61371/journal.pone.0067951.

Jenkins, M., Cumming, O., Scott, B., \& Cairncross, S. (2014). Beyond 'improved'towards 'safe and sustainable'urban sanitation: assessing the design, management and functionality of sanitation in poor communities of Dar es Salaam, Tanzania. Journal of Water, Sanitation and Hygiene for Development, 4(1), 131-141. 
Katukiza, A. Y., Ronteltap, M., Niwagaba, C. B., Foppen, J. W. A., Kansiime, F., \& Lens, P. N. L. (2012). Sustainable sanitation technology options for urban slums. Research review paper. Biotechnology Advances 30, 964-978.

Kulabako, R. N., Nalubega, M., Wozei, E., \& Thunvik, R. (2010). Environmental health practices, constraints and possible interventions in peri-urban settlements in developing countries - a review of Kampala, Uganda. International Journal of Environmental Health Research, 20(4), 231257.

Kwiringira, J., Atekyereza, P., Niwagaba, C., \& Günther, I. (2014a). Descending the sanitation ladder in urban Uganda: evidence from Kampala Slums. BMC public health, 14(1), 624.

Kwiringira, J., Atekyereza, P., Niwagaba, C., \& Günther, I. (2014b). Gender variations in access, choice to use and cleaning of shared latrines; experiences from Kampala Slums, Uganda. BMC public health, 14(1), 1180.

Mara, D. (1984). The design of Ventilated Improved Pit latrines Technology Advisory Group (TAG) Technical Note No.13. USA: International Bank for Reconstruction and Development/The World Bank.

Medland, L., Cotton, A., \& Scott, R. (2015). The SPLASH Urban sanitation research programme. Consolidated findings. Loughborough University, UK: Water, Engineering and Development Centre, (WEDC).

MOH-Uganda. (2000). National sanitation guidelines. Ministry of Health -Uganda. Kampala, Uganda: Water and Sanitation Program - Africa Region (WSP-AR).

Nyenje, P. M., Foppen, J. W., Kulabako, R., Muwanga, A., \& Uhlenbrook, S. (2013). Nutrient pollution in shallow aquifers underlying pit latrines and domestic solid waste dumps in urban slums. Journal of environmental management, 122(0), 15-24. doi: http://dx.doi.org/10.1016/j.jenvman.2013.02.040

Nyenje, P. M., Havik, J. C. N., Foppen, J. W., Muwanga, A., \& Kulabako, R. (2014). Understanding the fate of sanitation-related nutrients in a shallow sandy aquifer below an urban slum area. Journal of Contaminant Hydrology, 164(0), 259-274. doi: http://dx.doi.org/10.1016/i.jconhyd.2014.06.011

Rugadya, M. A., Nsamba-Gayiiya, E., \& Herbert, K. (2008). Slums in Uganda: situation analysis national slum upgrading strategy and action plan. Ministry of land, housing and urban development, Department of housing, Kampala.

Sonego, I. L., \& Mosler, H.-J. (2014). Why are some latrines cleaner than others? Determining the factors of habitual cleaning behaviour and latrine cleanliness in rural Burundi. Journal of Water, Sanitation and Hygiene for Development, 4(2), 257-267.

Struyk, R. J., \& Giddings, S. (2009). The Challenge of an Urban World: An Opportunity for U.S. Foreign Assistance. Washington D.C. USA: International Housing Coalition (IHC) (Available at: http://www.intlhc.org/docs/The Challenge of an Urban World.pdf accessed 6/8/2012).

Thye, Y. P., Templeton, M. R., \& Ali, M. (2011). A critical review of technologies for pit latrine emptying in developing countries. Critical Reviews in Environmental Science and Technology, 41(20), 17931819.

Todman, L. C., van Eekert, M. H., Templeton, M. R., Hardy, M., Gibson, W. T., Torondel, B., Abdelahi, F., \& Ensink, J. H. (2014). Modelling the fill rate of pit latrines in Ifakara, Tanzania.

Tsinda, A., Abbott, P., Pedley, S., Charles, K., Adogo, J., Okurut, K., \& Chenoweth, J. (2013). Challenges to achieving sustainable sanitation in informal settlements of Kigali, Rwanda. International journal of environmental research and public health, 10(12), 6939-6954.

Tumwebaze, K. I., Orach, G. C., Niwagaba, C., Luthi, C., \& Mosler, H. (2012). Sanitation facilities in Kampala slums, Uganda: users' satifaction and determinant factors. International Journal of Environmental Health Research, 1(1), 1-14. . 
UN-HABITAT. (2006). State of the World's Cities, 30 years of Shaping the Habitat Agenda. . UK and USA: Earthscan Publications

Ltd.

Available

at http://www.unhabitat.org/pmss/listltemDetails.aspx?publicationID=2101, accessed 6/8/2012.

UN-HABITAT. (2009). Planning Sustainable Cities: Global Report on Human Settlements 2009. UK and USA: Earthscan Lublications Ltd. Available at:http:// www.unhabitat.org/downloads/docs/GRHS2009/GRHS.2009.pdf accessed 6/8/2012

UNICEF, \& WHO. (2008). Progress on drinking water and sanitation. Special focus on sanitation.Available at: http://www.who.int/water_sanitation_health/monitoring/jmp2008/en/index.html, accessed 5/8/2012: WHO/UNICEF Joint Monitoring Program for Water Supply and Sanitation.

Wagner, E. G., \& Lanoix, J. N. (1958). Excreta disposal for rural areas and small communities. 